\title{
Effect of a Retention Basin on Removing Pollutants from Stormwater: A Case Study in Poland
}

\author{
Andrzej Walęga ${ }^{1 *}$, Katarzyna Wachulec ${ }^{2}$ \\ ${ }^{1}$ Department of Sanitary Engineering and Water Management, Faculty of Environmental Engineering \\ and Land Surveying, University of Agriculture in Kraków, Poland \\ ${ }^{2}$ DHI Poland, Kraków, Poland
}

Received: 14 July 2017

Accepted: 3 September 2017

\begin{abstract}
This paper presents an analysis of stormwater quality from urbanized catchments (roads) and the effects of its treatment with retention and retention-infiltration basins. The research was carried out on two types of objects: a retention-infiltration basin in Kraków and three reservoirs by Road No. 4 near the city. The following pollution indexes were analyzed: COD, total suspended solids and mineral suspended solids, reaction, chlorides, phosphates, and ammonium nitrogen. The research proved that COD, suspended solids, and chlorides played a crucial role in the quality of stormwater from the roads. The analysis of the main components of stormwater samples from the reservoir showed that the processes were determined by three major components that provided almost $93.0 \%$ of the total information on interactions between pollutants.
\end{abstract}

Keywords: stormwater, urban areas, pollution, PCA analysis

\section{Introduction}

Apart from ground and surface waters, rainwater belongs to water resources that can potentially be used by humans. As a result of urbanization and thus an increase in surface sealing in catchment areas, rainwater is frequently perceived as a problem or even a threat to people living in those areas [1]. This threat is associated not only with an excessive amount of water, but also with its quality. Urban and industrial areas alike represent accumulations of pollutants originating from streets, roofs, or open spaces. Pollution loads flushed from sealed surfaces during a rain or thaw may be harmful to water and soil environments [2-3]. The most contaminated

*e-mail: a.walega@ur.krakow.pl are runoff from communication routes [4-5]. As shown in research studies, runoff occurring after a long dry period is particularly hazardous [6-7]. Apart from total suspended solids, heavy metals, petroleum substances, or phosphorus compounds [8-10], they may contain pathogen loads, including E. coli and feces [11]. Pollutants carried by surface runoff reach their highest levels within the first 10-20 minutes from the beginning of a rain episode [1213].

Proper management of this water should become a primary objective of reasonable water management in urban areas. Traditional methods of discharging rainwater into sewage systems may be associated with numerous adverse effects, including soil degradation in urban areas due to its excessive dryness, sewage system overload, insufficient wastewater treatment during heavy rainfalls, or a drop in groundwater levels and depletion 
of their resources. According to Kaczor and Bugajski [4], thaw waters in winter represent $43-70 \%$ of daily inflow to a treatment plant, reducing the mean daily temperature of wastewater by $2-3^{\circ} \mathrm{C}$, and thus have a negative effect on certain processes, including nitrification. Apart from catching and draining the waters, the possibility of their subsequent reuse should also be ensured. Therefore, the basic principle for rainwater management in urban areas is managing rainwater at a place of its origination, so it cannot become precipitation wastewater. The best method for managing rainwater is its treatment, e.g., by temporary retention, and then its introduction into the ground by infiltration [14-18]. These solutions are often considered "best management practices" [19]. Therefore, currently the role of facilities for rainwater management in urban areas steadily increases in importance. With the correct selection of a filtration material, pollutants in water from stormwater will be stopped during the infiltration process, for example due to the presence of microorganisms in a bottom sediment layer. The facilities described above include retention-infiltration basin reservoirs. Solutions of this type have been implemented in water and wastewater management throughout the years $[12,20]$.

This study focuses on the problem of draining and treating stormwater from contaminated traffic surfaces. The main aspect of this report is an attempt to describe interactions between pollution indicators present in rainwater, and an attempt to generalize the factors affecting quality of this water in retentioninfiltration basin reservoirs. This issue remains relatively understudied in facilities of this type. For this purpose we applied the standard technique of principal component analysis (PCA), which is commonly used in studies on interactions between pollution indicators in rivers [2124], eutrophication process in lakes [25], and interactions between macroinvertebrates and water quality in rivers [26]. PCA has been successfully applied to sort out hydrogeological and hydrogeochemical processes from commonly collected groundwater quality data. The PCA technique is very useful in the analysis of data corresponding to a large number of variables, as it produces easily interpretable results. This method has been for years successfully used in hydrochemistry, surface-, and groundwater quality assessment and environmental research employing multi-component techniques [27-28]. PCA is used to search for new abstract orthogonal eigenvalues that explain most of the data variation in a new harmonized structure. Each principal component (PC) is a linear combination of the original variables and describes different source of information by eigenvalue based on the decomposition of the covariance/ correlation matrix [29]. PCA is designed to modify the observed variables into uncorrelated variables of linear combinations of the original variables, or PCs. This method is used to investigate the factors that caused variations in the observed datasets [29].

The aim of this paper was to evaluate the effectiveness of pollutant removal from stormwater in a retention- infiltration basin and retention reservoirs located near roads. Two types of facilities were analyzed in this study: a retention-infiltration basin reservoir in Kraków, and retention reservoirs located along the Kraków-Tarnów main road and associated with light liquid separators.

\section{Material and Methods}

\section{Description of Studied Facilities}

\section{Retention-Infiltration Basin in Kraków}

The studied facility is located in an urban and industrial part of the city. The reservoir location and shape, as well as the surface area of its basin, are determined by a railway embankment to the northwest, traffic grounds to the northeast and north, and undeveloped wasteland covered with bushes and single trees to the southwest. Its catchment area is mainly of an urban nature, characterized by the presence of impermeable surfaces, including asphalted carriageways, pavement, railway tracks and switches, and surfaces under buildings. Permeable surfaces are mainly represented by grasslands, wasteland covered with bushes, and cultivated land planted with vegetables. No stormwater drainage system has been installed in the analyzed area. The drained land is characterized by the presence of subcatchments with a varying surface runoff index. Total surface area of the retention-infiltration basin reservoir catchment area was 33.29 ha, with an average slope of $2.71 \%$. Average impervious cover in this catchment is $74.2 \%$.

A complex of facilities for intake, transport, storage, and treatment of precipitation wastewater flowing from the catchment area consists of (Fig. 1):

- Two concrete reduction chambers $(\mathrm{C} 1, \mathrm{C} 2)$ with sedimentation tanks located in roadside ditches near the railway viaduct along Półłanki street, with three 400-mm pipelines connecting the chambers.

- An open channel, $63 \mathrm{~m}$ long and $0.4 \mathrm{~m}$ wide at its bottom, installed with a slope of $2 \%$, secured with prefabricated concrete slabs and used to transport water from the reduction chambers to the reservoir; secured with rock armor at its outlet to absorb the impact energy of precipitation wastewater flowing in.

- A retention-infiltration basin reservoir with bottom area of 1,605 $\mathrm{m}^{2}$ and maximum capacity of $1,951 \mathrm{~m}^{3}$.

- Two piezometers.

The retention reservoirs are located along the Kraków-Tarnów road (Fig. 2). They are rectangular in shape, with slopes inclined at 1:1 and 1:2, secured with layers of geotextile, humus $(15 \mathrm{~cm})$, coarse sand $(15 \mathrm{~cm})$, geomembrane, and another layer of coarse sand $(10 \mathrm{~cm})$. The chambers at their inlets were reinforced with road slabs of reinforced concrete. The active capacity of the studied reservoirs does not exceed $400 \mathrm{~m}^{3}$. The catchment areas draining into the reservoirs are of a total area of 21.78 ha on average, with the sealed surface covering 2.50 ha on average. 


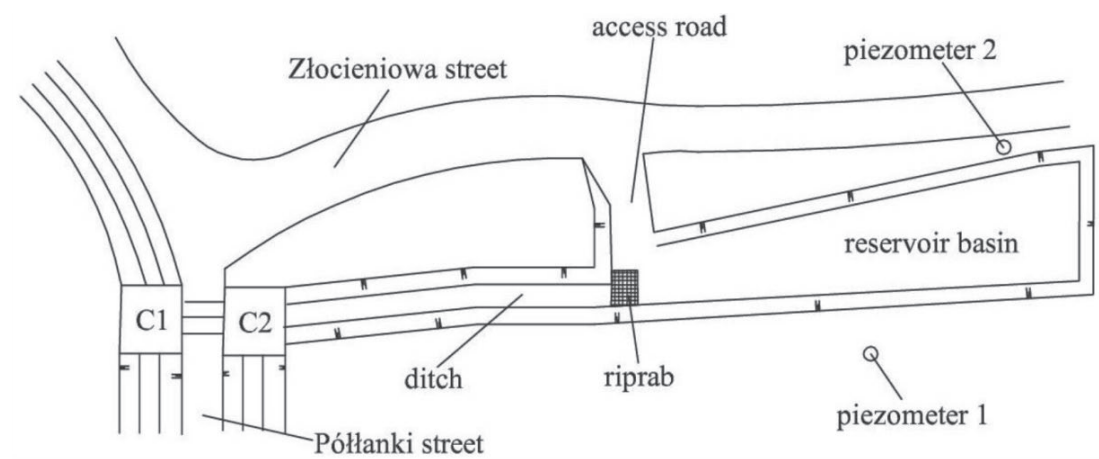

Fig. 1. A diagram of facilities for draining and treating water along Półłanki Street.

Additional facilities connected with the reservoirs are separators (installed upstream of the reservoir inlet) that separate petroleum substances from stormwater. Roadside ditches act as receiving bodies.

\section{Study Methods}

Samples of storm- and thaw-water runoff from traffic areas were collected from the end of March 2013 to May 2014. Sampling frequency was once a month. The samples were collected from the retention-infiltration basin reservoir in Kraków and from three Retention reservoirs along the Kraków-Tarnów main road in southern Poland. At the facility in Kraków the analyses focused on stormwater collected from a basin of the retention and infiltration reservoir, and from a piezometer installed downstream from the complex of treatment facilities. For the main road, analyses covered samples of stormwater collected from the retention reservoirs mentioned above.

The collected samples underwent physical and chemical analyses at the laboratory for the following pollution indices: COD, total suspended solids, sulphates, chlorides, phosphorus as orthophosphate, ammonium nitrogen, ether extract, and total iron, cadmium, zinc, copper, chromium, and lead. During each sampling, water temperature was measured directly on the spot. Furthermore, $\mathrm{pH}$ was determined at the laboratory.

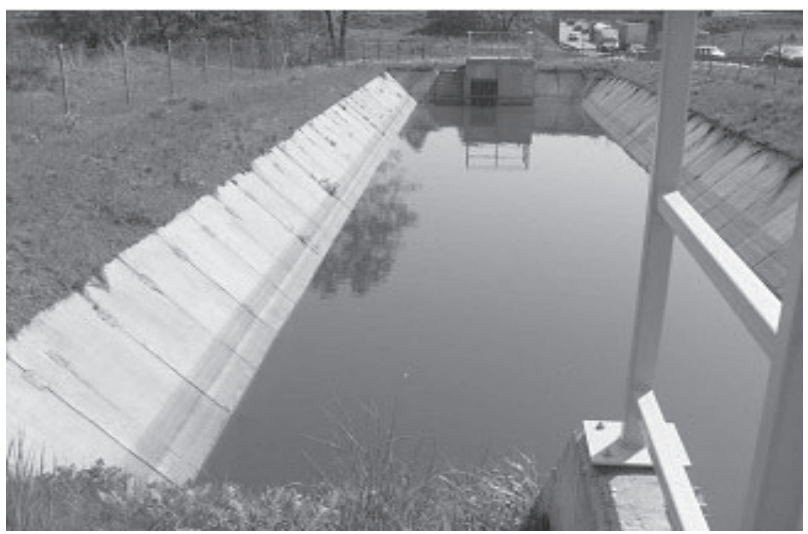

Fig. 2. Retention reservoir no 3 by the Kraków-Tarnów road (Photo A. Wałęga).
Additionally, heavy metal content in bottom sediments was analyzed for the reservoir in Kraków. Sediments were collected from the top layers using a bucket especially designed for this purpose. Five and four measurement series of heavy metal levels were conducted for wastewater and for bottom sediments, respectively. Total suspension was determined with the weighted method, $\mathrm{BOD}_{5}$ by defining oxygen concentration with the Winkler method at the beginning of the measurement. After 5 days of incubation COD was measured with a Spectro3Photometer, chlorides were determined by titration, and heavy metals using the atomic spectrophotometric method ASA. In the case of spectrophotometric methods for COD, nitrogen and phosphorus determination and tube tests were used and the measurements were conducted using calibrated devices.

The laboratory test results were analyzed statistically, with mean, minimum, maximum, standard deviation and coefficient of variation calculated for each index separately. These calculations were performed separately for individual collection points.

An analysis of main components was conducted to establish possible interactions between pollution indices in the Kraków reservoir. Such an analysis is very useful for a large number of correlated variables. The observed variables are transformed into a new set of uncorrelated variables. This way the number of variables is reduced, and a structure and general regularities in their interactions can be determined, while the studied items are described and classified in a new space defined by new factors.

An initial point for an algorithm used to analyze the main components is development of the input data matrix defined as:

$$
X=\left[x_{i j}\right] i=1,2, \ldots, n ; j=1,2, \ldots, m
$$

... where $\mathrm{x}_{\mathrm{ij}}$ is a value of the $j t h$ variable in the ith object. Then the variables are presented as a linear combination of main components:

$$
Z=W F
$$

...where: $\mathrm{Z}=\left[\mathrm{z}_{\mathrm{ji}}\right]$, or standardized observation matrix (m $\mathrm{x} \mathrm{n}$ ), where $\mathrm{z}_{\mathrm{ji}}$ is a value of the standardized $j$ th variable 
in the ith object; $\mathrm{W}=\left[\mathrm{w}_{\mathrm{j} 1}\right]$, or the matrix of the main component factors ( $\mathrm{n} \mathrm{x} \mathrm{s}$ ), where $\mathrm{w}_{\mathrm{jl}}$ is a value of a factor at the $j$ th variable and the $l$ th component; and $\mathrm{F}=\left[\mathrm{f}_{\mathrm{li}}\right]$, or the main components matrix ( $\mathrm{s} n$ ), where $\mathrm{f}_{\mathrm{li}}$ is a value of the lth main component at the ith object. A basis for determining elements for the matrix of main component factors is an $\mathrm{R}$ correlation matrix defined as:

$$
R=\frac{1}{n} Z^{T} Z
$$

To obtain factors of main components being elements of a vector $\mathrm{w}_{1}$, a system of $\mathrm{m}$-homogeneous equations with s-unknowns should be solved:

$$
\left(R-\lambda_{1} I\right) a_{1}=0
$$

...where $\mathrm{I}=[\operatorname{diag}(1)]$, or identity matrix (s $\mathrm{x} \quad \mathrm{s}) ; \lambda_{1}$ is characteristic root (eigenvalue) of the equation, corresponding to the first eigenvector; and $\mathrm{a}_{1}=\left[\mathrm{a}_{\mathrm{j} 1}\right]$ is normalized eigenvector (of eigenvalues) ( $\mathrm{m} \times 1$ ), corresponding to the first (the highest) characteristic root (eigenvalue).

On the basis of the determined eigenvector and its corresponding eigenvalue, the factors of the first main component were calculated:

$$
w_{1}=\sqrt{\lambda_{1}} a_{1}^{T}
$$

...where $\mathrm{w}_{1}=\left[\mathrm{w}_{\mathrm{j} 1}\right]$ vector ( $\left.\mathrm{m} \times 1\right)$, with factors of the first main component as elements.

Thus, the factor of the first main component in the equation of $\mathrm{jth}$ value was calculated from the formula:

$$
w_{j 1}=\sqrt{\lambda_{1}} \cdot \frac{a_{j 1}}{\sum_{j=1}^{m} a_{j 1}^{2}}
$$

Values of factors of the second main component are determined analogically to the first one [30]. When factors of the main components were determined, the values of the main components were established for individual objects. Statistical analysis were performed with significance level 5\%.

\section{Results and Discussion}

Table 1 presents collective qualitative characteristics of rainwater from the reservoir in Kraków. The mean values of the analyzed pollution indicators in the reservoir reached the following levels: $\mathrm{BOD}_{5}-8.7 \mathrm{mgO} \cdot \mathrm{dm}^{-3}$, $\mathrm{COD}-112.5 \mathrm{mgO}_{2} \cdot \mathrm{dm}^{-3}$, total suspended solids $-59.0 \mathrm{mg}$ $\cdot \mathrm{dm}^{-3}$, chlorides $-146.8 \mathrm{mg} \cdot \mathrm{dm}^{-3}$, ammonium nitrogen $-1.3 \mathrm{mg} \cdot \mathrm{dm}^{-3}$, and ether extract $-3.5 \mathrm{mg} \cdot \mathrm{dm}^{-3}$. Higher values were observed for phosphates. The pollutant levels in the retention-infiltration basin reservoir are determined by their sedimentation and mineralization, with participation of plants covering slopes of the conductor and the reservoir.
High levels of total suspended solids were observed in the reservoir following a long period of rain. This rainfall resulted in stormwater from the catchment area directly into the retention-infiltration basin reservoir, together with pollutants carried in it. It should be noted that during autumn months, when plant coverage of the catchment area is scarcer, surface runoff associated with rainfall increases erosion and washing out of some soil material, and, in consequence, significant quantities of those contaminants are carried into the reservoir. Higher levels of suspended solids also were present in the reservoir during spring and summer months, resulting from an intense runoff from the direct catchment area of the reservoir and flow of polluted wastewater from reduction chambers following heavy rainfalls. An increase in levels of total suspended solids in groundwater is mainly caused by washing off soil mineral components during infiltration. According to Kandra et al. [31] and Pedretti et al. [32], sediment concentration in stormwater is a significant parameter affecting hydraulic and treatment performance, eventually affecting longevity of these stormwater treatment systems. In the spring and summer season, a rise in COD values is also observed. The mean COD was $120.6 \mathrm{mg} \cdot \mathrm{dm}^{-3}$ in the period from March to July, and $101.6 \mathrm{mg} \cdot \mathrm{dm}^{-3}$ from August to February. This situation may be caused by the increased surface runoff from the direct catchment area of the reservoir. The exceptionally high COD value of $452.5 \mathrm{mg} \cdot \mathrm{dm}^{-3}$ may be a consequence of high air temperatures, which could have led to decomposition of organic matter accumulated on the reservoir bottom; with low oxygen values this process could result in high values of that indicator.

The presence of chlorides in stormwater is usually caused by use of their significant quantities to maintain roads in a good condition during winter [3]. Chloride concentration increase in catchments with relatively small amounts of urban land may be influenced by road salt, but may also be a result of other sources such as agricultural runoff, which is another potentially important source of chlorides in rural catchments [33]. Elevated salt concentration may also negatively impact aquatic life by decreasing biodiversity, increasing mortality rates of tadpoles, and decreasing the overall health of organisms [34-35]. Therefore, the highest values were observed in winter and during spring thaws. High values are present only in the reduction chambers directly supplied by runoff from roads. These values decrease significantly with wastewater flow through successive devices used for its treatment. Frequently, a slight increase in groundwater chloride levels was also observed. For chlorides present in samples of wastewater collected from the reservoir, a tendency for their higher levels during the spring and summer period is observed, versus the other months. This is influenced by reservoir supply from the direct catchment area. In spring this runoff carries a significant load of chlorides accumulated in the snow following treatment related to maintaining traffic flow on roads in winter. 
Table 1. Statistical characteristics of the analyzed pollution indices in the Kraków object.

\begin{tabular}{|c|c|c|c|c|c|c|}
\hline Pollution indicator & Average & $\begin{array}{c}\text { Confidence interval of mean. } \\
\pm 90 \%\end{array}$ & Maximum & Minimum & Range & $\begin{array}{l}\text { Standard } \\
\text { deviation }\end{array}$ \\
\hline \multicolumn{7}{|c|}{ Retention- Infiltration basin } \\
\hline $\mathrm{BOD}\left(\mathrm{mgO}_{2} \cdot \mathrm{dm}^{-3}\right)$ & 8.7 & 5.6-11.9 & 36.0 & 1.2 & 34.8 & 9.4 \\
\hline $\operatorname{COD}\left(\mathrm{mgO}_{2} \cdot \mathrm{dm}^{-3}\right)$ & 112.5 & $69.4-155.5$ & 452.5 & 16.3 & 136.2 & 94.6 \\
\hline Dissolved oxygen $\left(\mathrm{mgO}_{2} \cdot \mathrm{dm}^{-3}\right)$ & 8.6 & $8.0-9.3$ & 12.4 & 3.8 & 8.6 & 1.9 \\
\hline Concentration of $\mathrm{O}_{2}(\%)$ & 85.6 & $80.9-90.3$ & 111.2 & 67.4 & 43.9 & 12.9 \\
\hline $\mathrm{pH}$ value & - & - & 8.4 & 6.7 & 1.7 & - \\
\hline $\begin{array}{l}\text { Organic suspension solids } \\
\left(\mathrm{mg} \cdot \mathrm{dm}^{-3}\right)\end{array}$ & 59.0 & $35.0-82.9$ & 165.6 & 6.8 & 158.8 & 49.7 \\
\hline Sulfuric $\left(\mathrm{mgSO}_{4} \cdot \mathrm{dm}^{-3}\right)$ & 29.0 & $19.6-38.4$ & 103.4 & 2.5 & 100.9 & 26.9 \\
\hline Chlorides $\left(\mathrm{mgCl} \cdot \mathrm{dm}^{-3}\right)$ & 146.8 & $119.7-173.8$ & 468.1 & 39.0 & 429.1 & 80.8 \\
\hline $\begin{array}{l}\text { Ammonium nitrogen } \\
\qquad\left(\mathrm{mgNH}_{4} \cdot \mathrm{dm}^{-3}\right)\end{array}$ & 1.3 & $0.9-1.7$ & 4.6 & 0.001 & 4.6 & 1.2 \\
\hline Phosphates $\left(\mathrm{mgPO}_{4} \cdot \mathrm{dm}^{-3}\right)$ & 1.9 & $0.9-2.9$ & 13.0 & 0.03 & 13.0 & 2.9 \\
\hline Ether extracts $\left(\mathrm{mg} \cdot \mathrm{dm}^{-3}\right)$ & 3.5 & - & 7.8 & 0.8 & 7.0 & - \\
\hline Organic iron $\left(\mathrm{mgFe} \cdot \mathrm{dm}^{-3}\right)$ & 1.1 & $0.7-1.4$ & 3.5 & 0.2 & 3.4 & 1.0 \\
\hline Cadmium $\left(\mathrm{mgCd} \cdot \mathrm{dm}^{-3}\right)$ & 0.0002 & $0.0-0.0006$ & 0.0007 & 0.0 & 0.0007 & 0.0003 \\
\hline Lead $\left(\mathrm{mgPb} \cdot \mathrm{dm}^{-3}\right)$ & 0.004 & $0.001-0.007$ & 0.007 & 2.0 & 0.005 & 0.003 \\
\hline Zinc $\left(\mathrm{mgZn} \cdot \mathrm{dm}^{-3}\right)$ & 0.04 & $0.009-0.08$ & 0.08 & 0.002 & 0.06 & 0.03 \\
\hline Copper $\left(\mathrm{mgCu} \cdot \mathrm{dm}^{-3}\right)$ & 0.02 & $0.003-0.03$ & 0.04 & 0.02 & 0.03 & 0.01 \\
\hline Chromium $\left(\mathrm{mgCr} \cdot \mathrm{dm}^{-3}\right)$ & 0.001 & $0.0007-0.002$ & 0.002 & 0.001 & 0.0009 & 0.0005 \\
\hline Temperature $\left({ }^{\circ} \mathrm{C}\right)$ & 13.9 & $10.7-17.0$ & 31.0 & 0.0 & 31.0 & 9.4 \\
\hline \multicolumn{7}{|c|}{ Piezometr } \\
\hline $\mathrm{BOD}\left(\mathrm{mgO}_{2} \cdot \mathrm{dm}^{-3}\right)$ & 2.9 & $1.2-45.0$ & 24.0 & 0.4 & 23.6 & 5.3 \\
\hline $\mathrm{COD}\left(\mathrm{mgO}_{2} \cdot \mathrm{dm}^{-3}\right)$ & 100.2 & $67.2-133.2$ & 325.6 & 4.8 & 320.8 & 100.6 \\
\hline Dissolved oxygen $\left(\mathrm{mgO}_{2} \cdot \mathrm{dm}^{-3}\right)$ & 7.2 & $6.4-7.9$ & 12.4 & 2.2 & 10.2 & 2.3 \\
\hline Concentration of $\mathrm{O}_{2}(\%)$ & 62.1 & $55.8-68.4$ & 80.2 & 22.1 & 58.2 & 17.2 \\
\hline $\mathrm{pH}$ value & - & - & 7.0 & 6.4 & 0.6 & - \\
\hline $\begin{array}{l}\text { Organic suspension solids (mg · } \\
\left.\qquad \mathrm{dm}^{-3}\right)\end{array}$ & 61.5 & $45.4-77.5$ & 197.6 & 1.1 & 196.5 & 47.9 \\
\hline Sulfuric $\left(\mathrm{mgSO}_{4} \cdot \mathrm{dm}^{-3}\right)$ & 38.9 & $24.9-52.9$ & 180.5 & 2.3 & 178.2 & 40.8 \\
\hline Chlorides $\left(\mathrm{mgCl} \cdot \mathrm{dm}^{-3}\right)$ & 129.1 & $115.8-142.4$ & 187.9 & 53.2 & 134.7 & 40.5 \\
\hline $\begin{array}{l}\text { Ammonium nitrogen }\left(\mathrm{mgNH}_{4}\right. \\
\left.\mathrm{dm}^{-3}\right)\end{array}$ & 1.4 & $1.0-1.8$ & 4.52 & 0.02 & 4.50 & 1.2 \\
\hline Phosphates $\left(\mathrm{mgPO}_{4} \cdot \mathrm{dm}^{-3}\right)$ & 1.9 & $0.9-2.9$ & 10.0 & 0.02 & 10.0 & 2.8 \\
\hline Ether extract $\left(\mathrm{mg} \cdot \mathrm{dm}^{-3}\right)$ & 1.2 & $0.7-1.7$ & 4.9 & 0.2 & 4.7 & 1.2 \\
\hline Organic iron $\left(\mathrm{mgFe} \cdot \mathrm{dm}^{-3}\right)$ & 0.0001 & $0.00005-0.0002$ & 0.0002 & 0.00002 & 0.0002 & 0.00008 \\
\hline Cadmium $\left(\mathrm{mgCd} \cdot \mathrm{dm}^{-3}\right)$ & 0.01 & $0.005-0.02$ & 0.02 & 0.007 & 0.01 & 0.006 \\
\hline Lead $\left(\mathrm{mgPb} \cdot \mathrm{dm}^{-3}\right)$ & 0.1 & $0.05-0.12$ & 0.23 & 0.07 & 0.2 & 0.07 \\
\hline Zinc $\left(\mathrm{mgZn} \cdot \mathrm{dm}^{-3}\right)$ & 0.01 & $0.01-0.02$ & 0.02 & 0.01 & 0.009 & 0.004 \\
\hline Copper $\left(\mathrm{mgCu} \cdot \mathrm{dm}^{-3}\right)$ & 0.001 & - & 0.001 & 0.001 & 0.0 & 0.0 \\
\hline Chromium $\left(\mathrm{mgCr} \cdot \mathrm{dm}^{-3}\right)$ & 11.1 & $9.7-12.6$ & 19.0 & 2.0 & 17.0 & 4.4 \\
\hline
\end{tabular}


Table 2. Observed and acceptable contents of heavy metals in the investigated bottom sediments.

\begin{tabular}{|c|c|c|c|c|}
\hline $\begin{array}{c}\text { Pollution indica- } \\
\text { tor }\end{array}$ & $\begin{array}{c}\text { Average } \\
\left(\mathrm{mg} \cdot \mathrm{kg} \mathrm{s.m} .^{-1}\right)\end{array}$ & $\begin{array}{c}\text { Minimum } \\
\left(\mathrm{mg} \cdot \mathrm{kg} \mathrm{s.m} .^{-1}\right)\end{array}$ & $\begin{array}{c}\text { Maximum } \\
\left(\mathrm{mg} \cdot \mathrm{kg} \mathrm{s.m} .^{-1}\right)\end{array}$ & $\begin{array}{c}\text { Acceptable level for use in agriculture and for } \\
\text { rehabilitation of grounds for agricultural purposes } \\
\left(\mathrm{mg} \cdot \mathrm{kg} \mathrm{d} . \mathrm{w}^{-1}\right)\end{array}$ \\
\hline Cadmium & 0.3 & 0.2 & 0.4 & 20.0 \\
\hline Lead & 16.4 & 13.0 & 19.2 & 750.0 \\
\hline Copper & 27.6 & 11.7 & 63.9 & $1,000.0$ \\
\hline Zinc & 78.9 & 60.4 & 103.0 & 500.0 \\
\hline Chromium & 17.6 & 9.7 & 25.0 & 500 \\
\hline
\end{tabular}

Similar to phosphorus, the highest nitrogen levels are observed after long periods of rainfall, when it is carried into the reservoir with the runoff from the direct catchment area. In the samples of wastewater collected from the reservoir, the values of analyzed pollution indicators were characterized by a more stable course in time; and this is a consequence of treatment processes occurring upstream at the reduction chambers. The presence of heavy metals inhibiting nitrification processes in infiltrating wastewater, together with a short wastewater retention time in the ground, may be a cause for an increase in ammonium nitrogen levels during infiltration. During the infiltration process, a slight increase in phosphate levels is observed, caused by washing off from the ground of this form of phosphorus, accumulated on particles of suspended solids. It is also a consequence of too short a retention of wastewater in the ground bed, which does not promote absorption of this indicator. Absorption is also hindered by a particle size distribution in a deeper layer of the bed, which does not contain a sufficient quantity of the floatable fraction.

When analyzing cadmium levels in the reservoir and in groundwaters, it should be noted that they were similar, at a level of $0.0012 \mathrm{mg} \cdot \mathrm{dm}^{-3}$ for groundwaters and of $0.00022 \mathrm{mg} \cdot \mathrm{dm}^{-3}$ for water collected from the reservoir. However, no notable reduction in cadmium levels by infiltration was observed, as this metal was present in its soluble form. The mean lead level in the reservoir water was $0.0043 \mathrm{mg} \cdot \mathrm{dm}^{-3}$. During infiltration, wastewater lead levels gradually rose, and in the samples of groundwater collected from piezometer 2 it reached $0.010 \mathrm{mg} \cdot \mathrm{dm}^{-3}$.
This situation resulted from the fact that lead, usually present in its bound form, was accumulated in the bed already at relatively shallow levels. Other analyzed heavy metals, including zinc, copper, and chromium, showed similar tendencies as cadmium and lead discussed above.

Table 2 shows heavy metal contents in analyzed bottom sediments, as compared with acceptable values for their use for agricultural purposes or for rehabilitation of grounds, as provided for in the Regulation of the Minister of the Environment of 6 February 2015 [36].

Comparing heavy metal levels in sediments from the retention-infiltration basin reservoir with the regulation quoted above, it can be seen that they can be used for agricultural purposes without posing a threat to soil and groundwater quality.

For the retention reservoirs located by road No. 4, very high chloride levels should be noted, with their mean value of $2,244.0 \mathrm{mg} \cdot \mathrm{dm}^{-3}$, and their maximum value of 5,762.0 $\mathrm{mg} \cdot \mathrm{dm}^{-3}$ (Table 3 ). Chlorides are carried to the studied reservoirs with stormwater from the dual carriageway during thaws, and their presence results from operations aimed at maintaining traffic flow during periods of frost.

Similarly, significant quantities of suspended solids in waters of the studied reservoirs can also be explained by the influence of road traffic. When comparing results presented in Tables 1 and 3, it can be noted that in the reservoirs located by the main road the levels of analyzed pollution indicators were several times higher versus those observed in the retention-infiltration basin reservoir. This situation results for two reasons. First, the level of road traffic was higher on the main road versus Półłanki street;

Table 3. Statistical characteristics for analyzed pollution indicators from the retention reservoirs.

\begin{tabular}{|c|c|c|c|c|}
\hline Pollution indicator & Average & Minimum & Maximum & Standard deviation \\
\hline COD $\left(\mathrm{mgO}_{2} \cdot \mathrm{dm}^{-3}\right)$ & 188 & 10.00 & 609 & 189 \\
\hline $\begin{array}{c}\text { Total suspension solids } \\
\left(\mathrm{mg} \cdot \mathrm{dm}^{-3}\right)\end{array}$ & 324 & 15.20 & 934 & 302 \\
\hline Mineral suspension solids $\left(\mathrm{mg} \cdot \mathrm{dm}^{-3}\right)$ & 213 & 8.80 & 667 & 193 \\
\hline Chlorides $\left(\mathrm{mgCl} \cdot \mathrm{dm}^{-3}\right)$ & 2,244 & 70.92 & 5,762 & 1,988 \\
\hline Ammonium nitrogen $\left(\mathrm{mgNH}_{4} \cdot \mathrm{dm}^{-3}\right)$ & 0 & 0.10 & 1 & 0 \\
\hline Phosphates $\left(\mathrm{mgPO}_{4} \cdot \mathrm{dm}^{-3}\right)$ & 4 & 0.13 & 13 & 4 \\
\hline
\end{tabular}


Table 4. A matrix of correlation between studied pollution indicators in waters of the retention-infiltration basin.

\begin{tabular}{|c|c|c|c|c|c|c|}
\hline & COD & $\begin{array}{c}\text { Total suspension } \\
\text { solids }\end{array}$ & $\begin{array}{c}\text { Mineral suspension } \\
\text { solids }\end{array}$ & Chlorides & Phosphates & $\begin{array}{c}\text { Ammonium } \\
\text { nitrogen }\end{array}$ \\
\hline COD & 1.000 & -0.024 & 0.095 & 0.188 & 0.015 & -0.853 \\
\hline Total suspension solids & -0.024 & 1.000 & 0.989 & -0.647 & 0.962 & 0.0411 \\
\hline Mineral suspension solids & 0.095 & 0.989 & 1.000 & -0.638 & 0.935 & -0.087 \\
\hline Chlorides & 0.188 & -0.647 & -0.638 & 1.000 & -0.616 & -0.414 \\
\hline Phosphates & 0.015 & 0.962 & 0.935 & -0.615 & 1.000 & 0.115 \\
\hline Ammonium nitrogen & -0.853 & 0.041 & -0.087 & -0.414 & 0.115 & 1.000 \\
\hline
\end{tabular}

the studies there showed a strong correlation between the level of road traffic and levels of suspended solids in stormwater. The second reason was a lack of facilities for initial removal of suspended solid from runoff upstream of the retention reservoirs.

When determining processes occurring in rainwater reservoirs, an analysis of interactions between indicators characterizing a given pollution is of importance. This knowledge would allow for developing a model for pollution transformations in facilities for treatment of stormwater. In this paper, an analysis of PCA was used, which is still relatively rarely used in analyses associated with widely understood water and wastewater management, particularly in Poland. The analyses did not include heavy metals and ether extract due to an insufficient number of collected samples. The first step in the analysis is to determine coefficients of correlation between the analyzed parameters. Table 4 presents a correlation matrix for the analyzed pollution indicators in waters of the retention-infiltration basin reservoir in Kraków. The data presented in the table indicate that COD is most strongly correlated with ammonium nitrogen, and total suspended solids most strongly correlate with mineral suspended solids and phosphates. A similar situation was observed for mineral suspended solids, while chlorides most strongly correlated with all forms of suspended solids and with phosphates. The presented table shows that water of the studied reservoir contained groups of pollutants representative for evaluation of overall interactions between various chemical indicators.

An analysis of eigenvalues presented in Table 5 shows that 2 components can be generated from all factors. The first of them contributes more than $57.4 \%$ of information. Together, the first two components explain $80.9 \%$ of variations in the analyzed variables.

To make a final decision concerning the number of main components on which the further analyses would focus, the scree criterion was used. For this purpose, the scree plot was developed (Fig. 3). The figure shows that the scree starts with the 2 main components which, together with previous components, explains more than $80.0 \%$ of total information resources of the input variables. Thus, 3 factors were considered in further analyses.

The calculation results of resources of a common variable are shown in Table 6. According to that table,
Table 5. Values and cumulative eigenvalues of the principal components and percentages and cumulative percentages of the total variance.

\begin{tabular}{|c|c|c|c|c|}
\hline $\begin{array}{c}\text { Number } \\
\text { of values }\end{array}$ & $\begin{array}{c}\text { Eigenval- } \\
\text { ues }\end{array}$ & $\begin{array}{c}\text { \% of total } \\
\text { variance }\end{array}$ & $\begin{array}{c}\text { Cumulative } \\
\text { eigenvalues }\end{array}$ & $\begin{array}{c}\text { Cumulative } \\
\text { eigenvalues } \\
-\%\end{array}$ \\
\hline 1 & 3.45 & 57.4 & 3.45 & 57.4 \\
\hline 2 & 1.95 & 32.5 & 5.40 & 80.9 \\
\hline 3 & 0.44 & 7.4 & 5.84 & 97.4 \\
\hline 4 & 0.16 & 2.6 & 6.00 & 100.0 \\
\hline
\end{tabular}

Factor 1 brings the largest amount of information about suspended solids, chlorides, and phosphorus as orthophosphate. Factor 2 additionally brings information about COD and ammonium nitrogen.

The conducted analysis is summarized in the plot with configuration of points representing Factors 1 and 2 (Fig. 4). The conducted calculations showed that the total variance was explained in more than $57.0 \%$ by Factor 1 , in nearly $33.0 \%$ by Factor 2.

For the chart plotting Factors 1 and 2 (Fig. 4), there are interactions between phosphorus as orthophosphate, total and mineral suspended solids, and chlorides. Factor 2 is most strongly correlated with ammonium nitrogen and

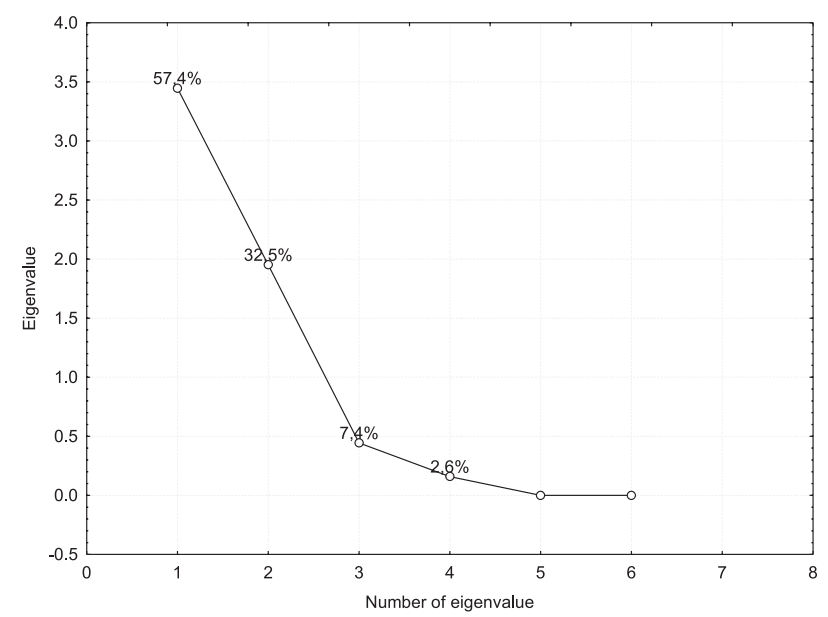

Fig. 3. Eigenvalues of the correlation matrix. 
Table 6. Values of common variable resources.

\begin{tabular}{|c|c|c|}
\hline \multirow{2}{*}{ Variable } & \multicolumn{2}{|c|}{ Common variable resources } \\
\cline { 2 - 3 } & From factor 1 & From factor 2 \\
\hline COD & 0.0026 & 0.446 \\
\hline Total suspension solids & 0.276 & 0.009 \\
\hline $\begin{array}{c}\text { Mineral suspension } \\
\text { solids }\end{array}$ & 0.265 & 0.033 \\
\hline Chlorides & 0.180 & 0.036 \\
\hline Phosphates & 0.265 & 0.0067 \\
\hline Ammonium nitrogen & 0.011 & 0.468 \\
\hline
\end{tabular}

COD. Additionally, the vectors for COD and ammonium nitrogen were arranged along the same lines, but on the opposite sides in relation to a center of the coordinate system. This means that these variables were maximally negatively correlated, and their coefficient of linear correlation was -1 .

COD, ammonium nitrogen, and chlorides did not correlate with any other indicators. Furthermore, COD and ammonium nitrogen vectors were perpendicular to each other, proving that there was absolutely no correlation between these variables.

The conducted analysis of the main components allowed us to determine two principal components describing interactions occurring in the retentioninfiltration basin reservoir. This analysis may be an introduction to further statistical conclusions based on a smaller number of variables (principal components), which additionally meet a postulate of independence, and this is of particular importance, e.g., in regression models.

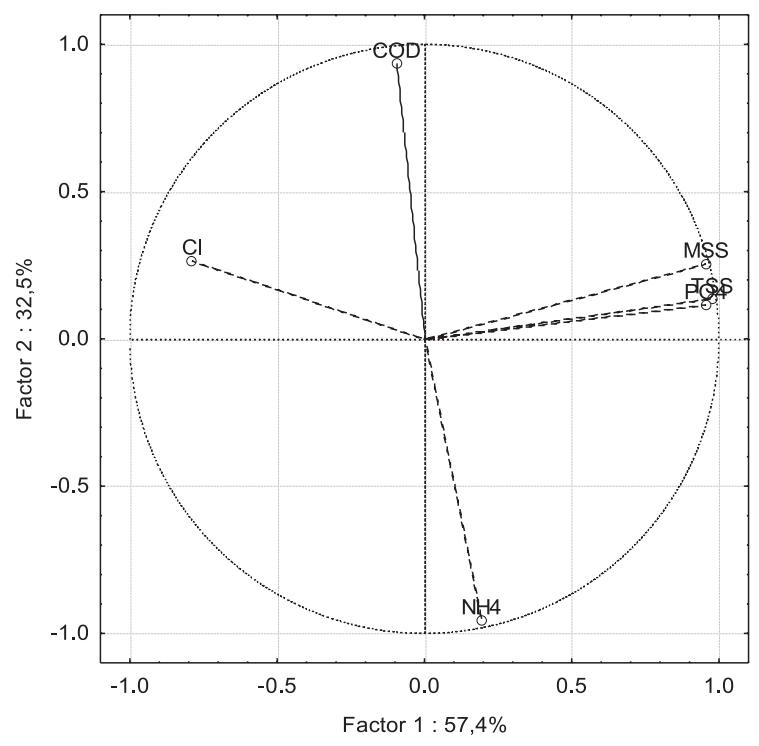

Fig. 4. Configuration of points representing factor variations.

\section{Conclusions}

The performed analyses allowed us to draw the following conclusions:

- COD, suspended solids, and chlorides play a dominant role in quality of stormwater from the traffic areas.

- Chloride levels in runoff are significantly influenced by season due to the use of chloride-containing products for fighting black ice on roads.

- Levels of total suspended solids in collected samples result from accumulation of dusts and mineral contaminations in the catchment area, which are washed away during heavy rainfall. The suspended solid levels are also influenced by surface runoff in the direct catchment areas of the reservoirs.

- Following the infiltration of precipitation wastewater, a slight increase in total suspended solids and ammonium nitrogen and phosphorus compounds was observed. This is caused by washing of mineral suspended solids and phosphates from the bed, and inhibiting the effect of heavy metals. However, no notable reduction in heavy metal levels by infiltration is observed due to various solubilities of those indicators in water.

- High levels of pollutants in the reservoirs located by road No. 4 result from a higher level of traffic on the main road versus the street at which the retention-infiltration basin reservoir is located, as well as from a lack of facilities for the initial removal of suspended solids from runoff upstream of the retention reservoirs.

- The analysis of principal components conducted for wastewater collected from the reservoir in KrakówBieżanów showed that processes occurring in it were determined by two main components, bringing in nearly $80.0 \%$ of all information about interactions between the pollutants. According to that analysis, Factor 1 brings the largest amount of information about suspended solids, chlorides, and phosphorus as orthophosphate. Factor 2 additionally brings information about ammonium nitrogen and COD.

\section{Acknowledgements}

The authors would like to thank for financial support the dean of the Faculty of Environmental Engineering and Land Surveying at the University of Agriculture in Kraków.

\section{References}

1. HALE R. Spatial and Temporal Variation in Local Stormwater Infrastructure Use and Stormwater Management Paradigms over the $20^{\text {th }}$ Century. Water 8 (310), 2016.

2. ERIKSSON E., BAUN A., MIKKELSEN P.S., LEDIN A. Chemical hazard identification and assessment tool for evaluation of storm water priority pollutants, Water Sci. Technol. 51, 47, 2005. 
3. HOU P., REN Y., ZHANG Q., LU F., OUYANG Z., WANG $\mathrm{X}$. Nitrogen and phosphorous in atmospheric deposition and roof runoff, Pol. J. Environ. Stud. 21 (6), 2012.

4. KACZOR G., BUGAJSKI P. Impact of snowmelt inflow on temperature of sewage discharged to treatment plant, Pol. J. Environ. Stud. 21 (2), 2012

5. WAŁEGA A., CUPAK A, PAWEŁEK J., MICHALEC B. Transform of pollutants in the stormwater treatment proces, Pol. J. Environ. Stud., 23, 3, 909, 2014.

6. TAEBI A., DROSTE R.L. First flush pollution load of urban stormwater runoff, Journal of Environmental Engineering and Science, 3, 4, 2004.

7. LI L.Q., YIN C.Q., HE Q.C., KONG L.L. First flush of storm runoff pollution from an urban catchment in China, Journal on Environmental Science, 19 (3), 2007

8. GONG Y., LIANG X., LI X., LI J., FANG X., SONG R. Influence of Rainfall Characteristics on Total Suspended Solids in Urban Runoff: A Case Study in Beijing, China. Water 8 (7), 2016.

9. MAO Y.J., GONG Q.Q., CHEN Y.C., YANG Z.M. Contamination characteristic of the runoff in Chongqing expressway, Resource and Environment in the Yangtze Basin, 19 (1), 2010.

10. BERNDTSSON J.C. Storm water quality of first flush urban runoff in relation to different traffic characteristics, Urban Water Journal 11, (4), 2011.

11. HATHAWAY J.M., HUNT W.F. Evaluation of first flush for indicator bacteria and total suspended solids in urban stormwater runoff, Water, Air \& Soil Pollution, 217 (1), 2011.

12. HVITVED-JACOBSEN T., VOLLERTSEN J, NIELSEN A.H. Urban and highway stormwater pollution. Concepts and Engineering. CRC Press. 2010.

13. LEE J.Y., KIM H., KIM Y., HAN M.Y. Characteristics of the event mean concentration (EMC) from rainfall runoff on an urban highway, Environmental Pollution, 159 (4), 884, 2011.

14. GULLIVER J., AHMED F., NIEBER J., HORWATICH J. Infiltration into a Roadside Grassed Swale. In: $13^{\text {th }}$ International Conference on Urban Drainage, Sarawak, Malaysia, 7-12 September 2014, 2014

15. HOANG L., FENNER R.A. System interactions of stormwater management using sustainable urban drainage systems and green infrastructure, Urban Water Journal, 13, 7 , 739, 2016.

16. ELLIS J.B. Sustainable surface water management and green infrastructure in UK urban catchment planning. Journal of Environmental Planning and Management, 56 (1), 24, 2013

17. MASETTI M., PEDRETTI D., SORICHETTA A. Impact of a Storm-Water Infiltration Basin on the Recharge Dynamics in a Highly Permeable Aquifer. Water Resources Management 149, 30, 149, 2016.

18. GÖBEL, P., ZIMMERMANN, J., KLINGER, C. Recommended urban storm water infiltration devices for different types of run-off under varying hydrogeological conditions. J Soils Sediments 8, 231, 2008 .

19. FLETCHER T.D, SHUSTER W., HUNT W.F., ASHLEY R., BUTLER D., SCOTT A., TROWSDALE S., BARRAUD S., SEMADENI-DAVIES A., BERTRANDKRAJEWSKI J-L., MIKKELSEN P.S., RIVARD G., UHL M., DAGENAIS D., VIKLANDER M. SUDS, LID, BMPs, WSUD and more -The evolution and application of terminology surrounding urban drainage, Urban Water Journal, 12 (7), 525-, 2015.

20. TORRES A., LIPEME KOUYI G., BERTRAND-KRA-
JEWSKI J. L., GUILLOUX J., BARRAUD S., PAQUIER A. Modelling of hydrodynamics and solid transport in a large stormwater detention and settling basin, Preceedings of the 11th International Conference on Urban Drainage, Edinburgh, Scotland, UK. 2008.

21. PETERSN W., BERTINO L., CALLIES U., ZORITA E. Process identification by principal component analysis of river water-quality data. Ecological Modelling 138, 193, 2001.

22. FAN X., CUI B., ZHAO H., ZHANG Z., ZHANG H. Assessment of river water quality in Pearl River Delta using multivariate statistical techniques. Procedia Environmental Sciences 2, 1220, 2010.

23. XU H.S., XU Z.X., WU W., TANG F.F. Assessment and Spatiotemporal Variation Analysis of Water Quality in the Zhangweinan River Basin, China. Procedia Environmental Sciences 13, 1641, 2012

24. RUŽDJAK A.M., RUŽDJAK D. Evaluation of river water quality variations using multivariate statistical techniques: Sava River (Croatia): A case study. Environmental Monitoring and Assessment 187 (4), 2015.

25. PARIET B., LHOTE A., LEGUBE B. Principal component analysis: an appropriate tool for water quality evaluation and management - application to a tropical lake system. Ecological Modelling 178, 295, 2004.

26. YURTSEVEN I., SERENGIL Y., PAMUKCU P. Seasonal changes in stream water quality and its effects on macroinvertebrate assemblages in a Forested watershed. Applied Ecology and Environmental Research 14 (1), 175, 2016.

27. PRAUS P. Water Quality Assessment Using SVD-Based Principal Component Analysis of Hydrological Data, Water SA 314, 417, 2005.

28. GAJBHIYE S., SHARMA S.K., AWASTHI M.K. Application of Principal Components Analysis for Interpretation and Grouping of Water Quality Parameters. International Journal of Hybrid Information Technology 8, 4, 89, 2015.

29. AYENI A.O., SONEYE A.S.O. Interpretation of surface water quality using principal components analysis and cluster analysis. Journal of Geography and Regional Planning 6 (4), 132, 2013.

30. PANEK T. Statistical methods of multidimensional comparative analysis. Publishing House School of Economics in Warsaw, Warsaw 2009 [In Polish].

31. KENDRA H., MCCARTHY D., DELETIC A. Assessment of the Impact of Stormwater Characteristics on Clogging in Stormwater Filters. Water Resources Management 29, 4, 1031, 2015.

32. PEDRETTI D., BARAHONA-PALOMO M., BOLSTER D., FERNANDEZ-GARCIA D., SANCHEZ-VILA X., TARTAKOVSKY D.M. Probabilistic analysis of maintenance and operation of artificial recharge ponds. Advances in Water Resources 36, 23, 2012.

33. CORSI S.R., DE CICCO L. A., LUTZ M.A., HIRSH R.M. River chloride trends in snow-affected urban watersheds: increasing concentrations outpace urban growth rate and are common among all seasons. Science of The Total Environment 508, 488, 2015.

34. CAÑEDO-ARGÜELLES M., KEFFORD B.J., PISCART C., PRAT N., SCHÄFER R.B., SCHULZ C.-J. Salinisation of rivers: an urgent ecological issue Environ. Pollut., 173, 157, 2013.

35. NOVOTNY E.V., STEFAN H.G. Projections of chloride concentrations in urban lakes receiving road de-icing salt. Water Air Soil Pollut., 211 (1-4), 261, 2010.

36. Regulation of the Minister of the Environment of 6 February regarding to municipal waste 2015 [In Polish]. 
